\title{
Using Youtube in Colleges of Education
}

\author{
A.Srinivasacharlu \\ Assistant Professor of Education \\ New Horizon College of Education (Aided), Bangalore, Karnataka, India
}

\section{OPEN ACCESS}

Volume: 8

Issue: 2

Month: March

Year: 2020

P-ISSN: 2320-2653

E-ISSN: 2582-1334

Received: 20.12.2019

Accepted: 19.01 .2020

Published: 01.03.2020

Citation:

Srinivasacharlu, A. "Using

Youtube in Colleges

of Education." Shanlax

Interational Journal of

Education, vol. 8, no. 2, 2020, pp. 21-24.

DOI:

https://doi.org/10.34293/

education.v8i2.1736

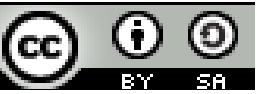

This work is licensed under a Creative Commons Attribution-ShareAlike 4.0 International License

\section{Abstract}

Present generation learners are growing up with digitalization. Educators are increasingly understanding and adapting new methods of teaching laced with digitalization. YouTube, an important off shoot of digitalization, is leading the charge as the most multipurpose medium for content transactions in the classroom and outside the classroom. It not only provides digital entertainment but also provides a great environment for learning. YouTube has multiple advantages for teacher educators and teacher trainees. Teacher educators and teacher trainees search YouTube for any information or clarification on a topic. Using YouTube in the classroom can bring efficiency in teaching and learning. Considering its endless services, there is no surprise that Youtube has been ranked the highest as a preferred learning tool. The teacher educators and teacher trainees can follow the prescribed procedures for creating and uploading effective videos on YouTube. Teacher educators can use YouTube in their class with all precautions and well planning.

Keywords: Digitalization, You Tube, Colleges of Education, Teacher Educators and Teacher Trainees

\section{Introduction}

Present generation learners are growing up with digitalization. Educators are increasingly understanding and adapting new methods of teaching laced with digitalization. YouTube, an important offshoot of digitalization, is leading the charge as the most multipurpose medium for content transactions in the classroom and outside the classroom. It not only provides digital entertainment but also provides a great environment for learning. YouTube is an American video-sharing website headquartered in San Bruno, California. Three former PayPal employees - Chad Hurley, Steve Chen, and Jawed Karim, created the service in February 2005. American Multi-national Company Google bought the site in November 2006.

\section{Meaning}

YouTube is a free web-based service that allows users to upload, view, rate, share, add to playlists, report, comment on videos, and subscribe to other users. It offers a wide variety of user-generated and corporate media videos. Available content includes video clips, TV show clips, music videos, short and documentary films, audio cassettes, movie trailers, live streams, and other content such as video blogging, short original videos, and educational videos. Unregistered users can only watch videos on the site, while registered users are authorized to upload an unlimited number of videos and add comments to videos. Videos deemed potentially inappropriate are available only to registered users declaring themselves to be at least 18 years old.

\section{Educational Uses}

Here are some of the specific advantages of You Tube for teacher educators and teacher trainees in the context of Colleges of Education: 


\section{A Place for Teacher Educators to Learn}

Teacher educators can learn more about their subjects and improve and strengthen their teaching skills by observing educational experts on YouTube.

\section{You Tube Videos are Interesting and Engaging}

The multimedia aspect of YouTube videos makes teacher trainees get fascinated in watching and learning more about the subjects.

\section{A Wealth of Resources from Experts}

You Tube provides for loads of experts who are sharing their knowledge and perspectives about different aspects or sub-disciplines within education for free.

\section{Visual and Audible Means of Learning}

The video medium of YouTube helps teacher trainees learn by both seeing and hearing. It makes them more engaged and be alert. This, in turn, helps them in better understanding and retention of the subject.

\section{Watchable Anytime and Place}

Teacher trainees can watch YouTube at any time and any place as long they have internet access.

\section{Videos can be Easily Shared}

Teacher educators and teacher trainees can easily search and review videos related to a specific concept or knowledge, and then provide to others with the link.

\section{Mobile Learning}

Teacher educators and teacher trainees can view You Tube via their smart phones and tablets.

\section{Student can Contribute themselves}

Students themselves can create original content and share their expertise with viewers. This is a great way for them to develop an online presence and have a creative way to show what they know.

\section{E-Learning Community}

You Tube permits everyone to have a voice. Teacher educators \& teacher trainees can use it as a social learning platform where everyone can comment, contribute \& share their opinions \& ideas.

\section{Micro-Learning}

You Tube ensures that complex procedures and demonstrations of specific skills are delivered in small quantities, which increases the retention of knowledge. Teacher trainees can watch the videos whenever they like and take their own time to absorb the information being offered.

\section{Permits Note Taking}

You Tube provides for note-taking by teacher trainees as it can be stopped in between and replayed until the content is fully grasped.

\section{Complex concepts can be Clarified}

Teacher educators can use YouTube for better illustration of complex concepts, procedures, processes, skills, etc. such as transgender, learning theories, micro-teaching, etc. Further, YouTube also provides for the display of accurate charts and graphs. Thus YouTube helps to demystify the tough concepts and make it easy for teacher trainees to understand and comprehend complex topics.

\section{Blessing for Slow Learners}

When using YouTube in the classroom, teacher educators have full control over the pace of learning. In case a slow learner, a group of slow learners among teacher trainees, finds a concept being explained too fast, they can request the part to be replayed, or it can be slowed down to play at a pace that will be easy for them to grasp.

\section{Global Connection}

Teacher educators and teacher trainees can share their videos with millions of people located in different parts of the world. They can collaborate, connect, and innovate with a multitude of people.

\section{Publicize about Institution}

Colleges of Education can use YouTube to promote themselves and reach out to wider audiences in the academic field. Short video clips containing interactive maps, campus facilities and important traditions and landmarks can be a great way to introduce students, other teacher educators, etc. to an institution.

\section{Alumni can be Updated}

YouTube can be used to keep former students involved and engaged in what's going on at their alma mater. Alumni can see campus activities and accomplishments. This can make Alumni feel engaged and informed about the current status of their alma mater, and they can recommend the institution to potential teacher trainees. 


\section{Uploading Videos in Youtube}

The teacher educators and teacher trainees can follow the following procedure for creating and uploading effective videos on YouTube:

- Limit videos to about ten minutes or less, unless one is trying to relay a great deal of information.

- Maintain a fervent tone to keep viewers engrossed.

- Properly balance different media, such as auditory and visual elements.

- Break videos into short segments by topic or theme.

- Include interactive and responsive features such as a short quiz, to promote reflection.

\section{Using Youtube in Classrooms}

Teacher educators can use YouTube in the following way in their class:

- Shorter YouTube clips (around five to 10 minutes) can help teacher trainees learn the information without being overloaded or losing their focus. Longer YouTube clips say around 30 minutes can also be effective when topic demands.

- Teacher educators can ensure captions and subtitles with videos as they are effective in helping teacher trainees to access and process information.

- It is essential that the teacher educators have seen the footage thoroughly before they show it to the class.

- They should make sure that YouTube should not completely replace the lesson.

- In short, to add interest to the class, teacher educators can choose a quick video that adds to or supports the information regarding the topic being taught.

- Teacher educators can create a YouTube channel that can contain all the videos relevant to a particular subject or lesson.

\section{Conclusion}

YouTube, a video-sharing website, provides good quality education. Teacher educators and teacher trainees search YouTube for any information or clarification on a topic. Using YouTube in the classroom can bring efficiency in teaching and learning. Considering its endless services, there is no surprise that YouTube has been ranked the highest as a preferred learning tool.

\section{References}

Bevan, Max. "Why Videos are Important in Education." Next Thought Studios, https:// www.next thoughtstudios.com/videoproduction-blog/2017/1/31/why-videos-areimportant-in-education.

Brown, Liza. "Tips for Teachers Using YouTube in Classroom." Filmora, https://filmora. wondershare.com/video-editing-tips/tips-forusing-youtube-in-classroom.html.

Burke, S.C. and Snyder, S.L. "YouTube: An Innovative Learning Resource for College Health Education Courses." International Electronic Journal of Health Education, vol.11, 2008, pp. 39-46.

Chtouki, Y. et al. "The Impact of YouTube Videos on the Student's Learning." International Conference on Information Technology Based Higher Education and Training, 2012, pp. 1-4.

DeWitt, Dorothy, et al. "The Potential of Youtube for Teaching and Learning in the Performing Arts." Procedia - Social and Behavioral Sciences, vol. 103, 2013, pp. 1118-1126.

Fralinger, Barbara. and Russell Owens. "You Tube as a Learning Tool." Journal of College Teaching \& Learning, vol. 6, no. 8, 2009, pp. $15-28$

Genota, Lauraine. "Why Generation Z Learners Prefer YouTube Lessons Over Printed Books." Education Week, 2018. https://www. edweek.org/ew/articles/2018/09/12/whygeneration-z-learners-prefer-youtube-lessons. html.

Moghavvemi, Sedigheh. et al. "Social Media as a Complementary Learning Tool for Teaching and Learning: The Case of Youtube." The International Journal of Management Education, vol. 16, no. 1, 2018, pp. 37-42.

Nicole Buzzetto-More. "Student Attitudes Towards the Integration of YouTube in Online, Hybrid, and Web-Assisted Courses: An Examination of the Impact of Course Modality on 
Perception." MERLOT Journal of Online Learning and Teaching, vol. 11, no. 1, 2015, pp. 55-73.

Portugal, K.O. et al. "Free-Choice Teaching: How YouTube presents a New Kind of Teacher." Revista Electrónica de Enseñanza de las Ciencias, vol. 17, no. 1, 2018, pp. 183-199.

Saurabh, Samant, and Sanjana Gautam. "Modelling and Statistical Analysis of YouTube's Educational Videos: A Channel Owner's Perspective." Computers \& Education, vol. 128, 2019, pp. 145-58.

Sumarie Roodt and Dominic Peier. "Using Youtube (C) in the Classroom for the Net Generation of Students." Issues in Informing Science and Information Technology, vol. 10, 2013, pp. 473-488.
"Top 20 Ways to Use YouTube in the Classroom." Educational App Store, https://www. educationalappstore.com/blog/top-20-waysto-use-youtube-in-classroom/.

Wael Abdulrahman Almurashi. "The Effective Use of Youtube Videos for Teaching English Language in Classrooms as Supplementary Material at Taibah University in Alula." International Journal of English Language and Linguistics Research, vol. 4, no. 3, 2016, pp. 32-47.

Watson, Catie. "Advantages \& Disadvantages of Electronic Gadgets." Techwalla, https:// www.techwalla.com/articles/advantagesdisadvantages-of-electronic-gadgets.

"Why YouTube is Important for Teachers and Students." Query Floor. https://www. queryfloor.com/blog/why-youtube-isimportant-for-teachers-and-students.

\section{Author Details}

A.Srinivasacharlu, Assistant Professor of Education, New Horizon College of Education (Aided), Bangalore, Karnataka, India, Email ID: asrinivasacharlu@gmail.com 